\title{
Çanakkale İlinde Tarım Sektörünün Genel Yapısı
}

\section{Arif SEMERCi ${ }^{* 1}$ iD \\ ${ }^{1}$ Çanakkale Onsekiz Mart Üniversitesi Ziraat Fakültesi Tarım Ekonomisi Bölümü, Terzioğlu Kampüsü, Merkez, Çanakkale}

Öz: Çanakkale ili Türkiye'nin önemli tarımsal üretim potansiyeline sahip illerinden biridir. Bu çalışmada Çanakkale ilinde tarım sektörünün genel yapısı ülke değerleriyle karşılaştırmalı olarak verilmeye çalışılmıştır. Çanakkale ili ülke nüfusunun \%0.66'sını, yüzölçümünün ise \%1.29'unu karşılamaktadır. ílin Türkiye tarımsal üretim değerindeki payı \%1.97 olup, bu pay hayvansal üretimde $\% 1.45$, bitkisel üretimde ise $\% 2.24$ olarak gerçekleşmiştir. Çanakkale ili kişi başına bitkisel üretim değerinde ülke genelinde 4., hayvansal üretimde ise 17. sırada yer almaktadır. Illin bitkisel üretim değerinde zeytin, buğday, domates, şeftali ve biberin payı $\% 46$ 'dır. II, Türkiye'nin önemli zeytin üretim merkezlerinden biri olup, ülke zeytin alanlarında \%4.93, üretim miktarındaki ise $\% 9.84$ paya sahiptir. Çanakkale ilinin ülke şeftali üretimindeki payı ise \%16'dır. Illde ekonomik büyüklük olarak ilk sıralarda yer alan tarımsal ürünlerin verim değerleri ülke ortalamasına göre daha yüksek düzeydedir. Ilin Türkiye süt üretimindeki payı \%2.63 olup, bu oran keçi sütünde \%8'dir. Çanakkale ili, saanen keçi varlığında Türkiye'nin en önemli damızlık merkezlerinden birisi konumundadır. İlde traktör ve biçerdöver başına düşen tarım alanı ülke ortalamasının altındadır. Bununla birlikte ilin süt sağım makinası ve silaj makinası varlığının ülke genelindeki payı \%3'ün üzerindedir. Çanakkale ilinde Çiftçi Kayıt Sistemi'ne kayıtı çiftçi sayısı yaklaşık 22 bin adet olup, ilde tarımsal üretime yönelik olarak 136 milyon , çiftçi başına ise yaklaşık 6.2 bin $€$ destekleme ödemesi yapılmıştır. Illde üretici başına ortalama destekleme tutarı ülke genelinden $\% 2.17$ daha yüksektir.

Anahtar Kelimeler: tarımsal yapı, üretim deseni, destekleme, Çanakkale

\section{General Structure of Agriculture Sector in Çanakkale Province}

Abstract: Çanakkale is one of the cities in Turkey which has an important agricultural production potential. In this study, the general structure of the agricultural sector in the province of Çanakkale has been given to be compared with the country values. Çanakkale city provides $0.66 \%$ of Turkey's population, and it holds $1.29 \%$ of Turkey's total area. Çanakkale city provides $1.97 \%$ of Turkey's agricultural production which are $1.45 \%$ in husbandry and $2.24 \%$ in vegetative production. Çanakkale is the $4^{\text {th }}$ city in Turkey in terms of vegetative production value per person, and it is $17^{\text {th }}$ in husbandry. $46 \%$ of the city's vegetative production is consisted of olive, wheat, tomato, peach, and pepper. Çanakkale is also an important olive production center in Turkey which holds $4.93 \%$ of olive production areas of the country, and it provides $9.84 \%$ of the total olive production. In addition to that, the share of city's in Turkey's peach production is $16 \%$. Productivity values of Çanakkale city in agricultural production are above the country average. The share of the city in Turkey's milk production is $2.63 \%$, and it is $8 \%$ in goat milk. Çanakkale city is also an important place in breeding goat. The numbers of tractor and combine harvester per agricultural area is below the Turkey's average. Yet, the city holds over 3\% of Turkey's milking machine and silage machine. There are nearly 22 thousand farmers who are registered to Farmer Registration System (FRS). The value of agricultural subsidy for Çanakkale that was provided by Ministry of Food, Agriculture and Livestock was approximately136 million $€$ in total, and it was 6.2 thousand $€$ per producer which was $2.17 \%$ more than the country average.

Keywords: agricultural structure, subsidy, production pattern, Çanakkale.

\section{GiRiş}

Tarım sektörü birçok sosyo-ekonomik ölçüt bakımından ülke ekonomilerinde gelişmişlik düzeylerine bağlı olarak farklı düzeyde öneme sahiptir. Sektör, sahip olduğu dezavantajlı özellikler nedeniyle özellikle gelişmiş ülkeler başta olmak üzere dünya genelinde destekleyici politikalarla korunmaktadır. Diğer ülkelerde olduğu gibi Türkiye'de de uygulanmakta olan tarım politikalarıyla üreticilerin gelir ve refah düzeylerini artırılması, tarımsal ürünlerde fiyat istikrarının sağlanması, kırsal kalkınma hedeflenmektedir. Türkiye, tarımsal üretim değeri bakımından dünyada 7., Avrupa ülkeleri arasında ise ilk sırada yer almaktadır (Aytüre ve Acar, 2016). Türkiye'de tarımsal üretim miktarı ve değeri bakımından bazı ürünlerde (zeytin, şeftali, domates, biber ve su ürünleri) Çanakkale ili ön plana çıkmaktadır.
Çanakkale ili, Balkan Yarımadası'nın Doğu Trakya topraklarına bir kıstakla bağlanmış, Gelibolu Yarımadası ile Anadolu'nun batı uzantısı olan Biga Yarımadası üzerinde yer almakta olup, 9,933 km²lik bir alanı kapsamaktadır (Anonim, 2018a).

Çanakkale ili sahip olduğu arazi varlığı, iklimi, su ürünleri potansiyeli ve hayvan varlığı ile bölgesinde ve ülke genelinde önemli bir yere sahiptir. İl, Türkiye'de süt üretimine dayalı, koyun-keçi yetiştiriciliğinin ve süt sığırcılığının yapıldığı önemli merkezlerden biridir. Süt sığırcılığında ve süt keçiciliğinde yüksek verimli damızlık hayvanların olması, ilin güçlü yönlerinden birini

Sorumlu Yazar: arifsemerci@comu.edu.tr

Geliş Tarihi: 23 Ekim 2018

Kabul Tarihi: 23 Haziran 2019 
oluşturmaktadır.

Çanakkale ilinin sosyo-ekonomik yapısı ve tarımsal üretim özellikleri yönünden inceleyen çalışmalar oldukça kısıtlı düzeydedir. 2005 yılında Çanakkale İlinin Ekonomik Gelişmesi üzerine geniş katılımlı bir seminer düzenlemiş (Anonim, 2005), 2011 yılında ise Çanakkale tarımı üzerine bir kongre düzenlenmiş, kongrede tüm detayları ile Çanakkale tarımını incelenmiştir (Anonim, 2011). Bununla birlikte Türkiye İstatistik Kurumu (TÜIK) ve Güney Marmara Kalkınma Ajansı (GMKA) tarafından hazırlanan Çanakkale iline yönelik gerek genel gerekse tarım sektörüne yönelik yayınlar bulunmaktadır (Anonim, 2014; Anonim, 2017a,b). Illin tarımsal üretim özellikleri dikkate alındığında farklı konularda yapılan araştırmalara kısaca altta değinilmiştir.

Koyuncu ve ark.(2006) tarafından Çanakkale ilindeki süt keçisi yetiştiriciliğine yer veren tarım işletmelerinin yapısal özelliklerinin belirlenmesi amacıyla il merkezine bağı 9 köyde 20 işletme ile anket uygulaması çalışması yapılmıştır. Aktaş ve Tan (2007) tarafından yapılan bir çalışmada dünyada ve Türkiye'de bağ alanlarının ve üretimin dağılımı, dış ticaret miktarları, bağcılığa alternatif olan zeytin ekim alanları ve üretiminin dağılımı, dünyada ve Türkiye'de şarap üretimi ve dış ticareti, bağcılıkla ilgili destekleme ve fiyat politikaları, son olarak da Çanakkale ilinde bağcılığın mevcut durumu incelenmiştir.

Aktürk ve ark. (2010) tarafından Çanakkale ili Biga ilçesinde yürütülen bir araştırmada süt üretimi ile süt üretiminde kullanılan faktörler arasındaki ilişki analiz edilmiş ve süt üretimi maliyeti hesaplanmıştır. Araştırma sonucunda; yem ve konsantre yem maliyetlerinin toplam üretim maliyetlerinin \%57'sini ve değişken maliyetlerin de \%71'ini oluşturduğu tespit edilmiştir. Araştırmada $1 \mathrm{~kg}$ süt maliyeti 0.29 ABD\$ olarak hesaplanmış olup, süt üretiminde en önemli girdiler ise silajlık mısır ve arpa olarak tespit edilmiştir.

Tan ve ark. (2014) yapmış oldukları çalışmada Türkiye'de tarımsal destekleme politikalarının genel bir özeti yapılmış, Tarım ve Orman Bakanlığı tarafından uygulanan tarımsal destekler; hayvancılık, organik tarım ve iyi tarım, mazot, gübre, toprak analizi, sertifikalı fidan ve tohum desteği, tarımsal danışmanlık destekleri ve havza bazlı destekler konuları baz alınarak Çanakkale ili özelinde incelenmiştir.

Aydın ve ark. (2015) yürütmüş oldukları araştırmada Kırklareli, Edirne, Tekirdağ ve Çanakkale illerinde iyi tarım uygulaması yapan ve yapmayan tarım işletmeleri incelenmişlerdir. Ilgar (2016) çalışmasında Çanakkale ilinin en önemli ürünlerinden olan zeytin tarımı hakkında gerek teknik gerekse istatistiki yönden bilgi vermiştir. Ilgar çalışmasında ilde zeytin üreticilerinin maliyet ve düşük fiyat politikalarından olumsuz yönde etkilendiklerini vurgulamış, sürme, ot, salgın hastalık ve ulaşım güçlüğünün zeytin yetiştiriciliğinde çözüm bekleyen en önemli sorunlar olduğu sonucuna varmıştır.

Ilgar (2017) tarafından yapılan bir çalışmada Çanakkale ilinde tarımda sürdürülebilirlik ve organik tarım konusu incelenmiştir. Çalışmada Çanakkale ilinde organik tarımın gelişiminin Türkiye tarımının gelişimi ile paralellik arz ettiği, son yıllarda ise ülke genelinde olduğu gibi, ilde de organik tarım üreticisi ve ürün miktarında artış yaşandığı tespit edilmiştir. Çalışma sonunda 2000- 2013 yılları arasında organik üretimi ve üretici sayısında önemli düzeyde yaşandığı, bu değişimde uygulanan desteklerin ve kredilerin önemli bir rolünün olduğu vurgulanmıştır.

Everest ve ark. (2018) tarafından yapılan bir çalışmada ise Çanakkale illinde faaliyet gösteren tarım işletmelerinin örgütlenme yapıları nicel verilerle ortaya konulmuştur. Bu çalışmada Çanakkale ilinin tarımsal yönden genel bir değerlendirilmesi yapılmıştır. Çalışmada; arazi varlığı, tarım alanları ve kullanım durumu, sulama, tarımsal işletme varlığı, bitkisel üretim, hayvansal üretim, su ürünleri üretimi, ilin alet-ekipman varlığı, tarımsal örgütlenme ve tarımsal destekler konuları incelenmiştir. Bu amaçla çalışmada kullanılan veriler Türkiye değerleriyle karşılaştırmalı olarak verilmiştir. Çalışmanın son bölümünde Çanakkale ilinde tarımsal üretimde karşılaşılan sorunlara yönelik çözüm önerileri sunulmuştur.

$\mathrm{Bu}$ çalışmanın temel verilerini Türkiye İstatistik Kurumu (TÜiK), Tarım ve Orman Bakanlığı (TOB), TOB Çanakkale iı Müdürlüğü, Güney Marmara Kalkınma Ajansı (GMKA) ve konu ile ilgili diğer kurum ve kuruluşlardan elde edilen veriler oluşturmaktadır. Ülke geneline ait verilerde Tüik verilerinin yanı sıra TOB Bitkisel Üretim Genel Müdürlüğü (BÜGEM) ve Hayvansal Üretim Genel Müdürlüğü (HAYGEM) kayıtlarından faydalanılmıştır. Verilerin yorumlanmasında, hazırlanan çizelgelerin analizi ve yüzde hesaplamalarından yararlanılmıştır. Çalışma kapsamında Çanakkale ilinin tarımsal yapısıyla ilgili olarak hazırlanan raporlar, yayınlar ve tezlerden faydalanılmıştır. Bu aşamada özellikle TOB Çanakkale il Müdürlüğü'nce hazırlanan brifing raporları ve çalışma raporlarından yararlanılmıştır. Çalışmada Çanakkale ilinin tarım alanları, hayvan varlığı ve hayvansal üretim miktarları Türkiye verileriyle karşılaştırmalı olarak verilmiştir.

Çalışma kapsamında Çanakkale ilinin tarımsal üretim değerleri (bitkisel ve hayvansal üretim miktarlarıyla birlikte) ayrıntılı olarak verilmiş olup, tarımsal destekleme uygulamaları ülke değerleriyle kıyaslamalı olarak verilmiştir. $\mathrm{Bu}$ aşamada TOB tarafından hazırlanan çalışma raporlarından faydalanılmıştır. Bu bağlamda hem Türkiye hem de Çanakkale ili için Çiftçi Kayıt Sistemi (ÇKS) verilerinden yararlanılmıştır. İlde üretici başına tarımsal destek miktarı ülke ortalama değeriyle karşılaştırılmıştır. 
Bununla birlikte çalışmada 2017 yılı itibariyle ildeki tarımsal örgütlenme durumuna da yer verilmiştir. Çalışmada ayrıca Çanakkale ve Türkiye genelinde tarımsal üretimde kullanılan traktör, biçerdöver, mibzer, pülverizatör, süt sağım makinası varlığı verilmiş ve ilin belirtilen alet-makine varlığındaki payı yorumlanmıştır.

\section{MAKRO EKONOMIK VERILERLE TÜRKIYE TARIMI}

Tarımın bir ülke ekonomisindeki yeri genel olarak; nüfus ve işgücüne katkısı, üretim ve verime katkısı, toplum beslenmesine katkısı, sanayi sektörüne katkısı, milli gelire ve dış ticarete katkısı olmak üzere altı grupta incelenebilir (Semerci, 2016). 2017 yılı Tüik verilerine göre Türkiye'nin nüfusu yaklaşık 80.8 milyon kişidir. Kırsal nüfusun toplama oranı ise \%7.5'dir. Ülkede yıllık nüfus artış oranı \%1.24 olarak gerçekleşmiştir (Anonim, 2018b).

2017 yılında Türkiye'nin toplam işgücü yaklaşık 31.6 milyon kişi, toplam istihdam 28.2 milyon kişi olup, aktif nüfusun sektörler göre dağılımı şöyledir; Hizmetler sektörü \%54.09, tarım sektörü \%19.38, sanayi sektörü \%19.10, inşaat sektörü \%7.43. Aynı yıl cari fiyatlarla Türkiye'nin Tarımsal Gayrisafi Yurtiçi Hâsıla (TGSYIH) değeri 52.1 milyar ABD\$ olup, tarımın ülke Gayrisafi Yurtiçi Hâsıla (GSYiH) içindeki payı \%6.12 olarak gerçekleşmiştir (Anonim, 2018c). Türkiye'nin 2017 yılı ihracatında tarım, balıkçılık ve gıda ürünlerinin değeri yaklaşık 16.4 milyar ABD\$ olup, toplamdaki payı \%10.44, ithalatında aldığı değer ise yaklaşık 13.9 milyar ABD\$, toplamdaki payı ise \%5.93 olarak gerçekleşmiştir. 2017 yılı itibariyle Türkiye'nin tarım, balıkçılık ve gıda ürünleri dış ticareti yaklaşık olarak 2,5 milyar ABD\$ fazla vermiş olmasına rağmen, gıda ürünleri ve işlenmiş tarım ürünleri hariç tutulduğunda tarımla ilgili dış ticaretinin açık verdiği anlaşılmaktadır (Anonim, 2018d).

Çizelge 1. Çanakkale ilinde tarım arazilerinin dağılımı (2017)

\begin{tabular}{llllll}
\hline İ̧lenebilir Arazi Dağılımı & $\begin{array}{l}\text { Türkiye } \\
\text { (ha) }\end{array}$ & $\begin{array}{l}\text { Payı } \\
(\%)\end{array}$ & $\begin{array}{l}\text { Çanakkale } \\
\text { (ha) }\end{array}$ & $\begin{array}{l}\text { Payı } \\
\text { (\%) }\end{array}$ & $\begin{array}{l}\text { Çanakkale/ } \\
\text { Türkiye (\%) }\end{array}$ \\
\hline Tarla Alanı (Nadas Dahil) & $19,810,496$ & 82.78 & 255,025 & 76.90 & 1.29 \\
Sebze Alanı (Örtü Altı Dahil) & 844,019 & 3.53 & 20,340 & 6.13 & 2.41 \\
Meyve Alanı & $2,013,192$ & 8.41 & 19,246 & 5.80 & 0.96 \\
Bağ Alanı & 416,907 & 1.74 & 4,682 & 1.41 & 1.12 \\
Zeytin Alanı & 846,062 & 3.54 & 32,340 & 9.75 & 3.82 \\
TOPLAM & $23,930,676$ & 100.00 & 331,633 & 100.00 & 1.39 \\
\hline
\end{tabular}

Kaynak: Anonim (2018a,f).

Türkiye'de toplam tarım alanları içinde tarla bitkilerine ayrılan alan Çanakkale iline göre daha yüksektir. Çanakkale ilinde sebze üretimine ayrılan alan ülke ortalamasının yaklaşık 2 katı düzeyindedir. İldeki bağ alanı ülke dağıımına yakın iken, meyvelik alan daha düşük, zeytin alanları ise ülke dağılımına göre 3 kat daha yüksek düzeydir (Çizelge 1).

\section{Tarım İşletmelerinin Yapısı}

2017 yılı verilerine göre Çanakkale ilinde 48.7 bin tarımsal işletme mevcut olup bunlardan 22 bin işletme (\%45.13) ÇKS'ye kayıtlıdır. il genelinde işletme başına düşen arazi

\section{ÇANAKKALE İLINDE TARIM SEKTÖRÜ}

Çanakkale ilinde idari yönden 12 ilçe, 11 belde, 576 köy, 79 köy bağlısı ve 23 belediye bulunmaktadır İlin 2017 yılı toplam nüfusu yaklaşık 530 bin kişi olup, ülke toplam nüfusundaki payı $\% 0.66$ 'dır. İlde nüfus yoğunluğu 53 $\mathrm{kişi} / \mathrm{km}^{2}$ olup, ülke değerinin $\left(105 \mathrm{kişi} / \mathrm{km}^{2}\right)$ oldukça altındadır (Anonim, 2018b). ì nüfusunun \%60.29'u il ve ilçe merkezlerinde, \%39.71'i ise belde ve köylerde yaşamaktadır. illin tarımsal faaliyetlerle ilgilenen nüfusu yaklaşık 181 bin kişi olup, toplam nüfusa oranı \%34.06'dır. Çanakkale ilinin iklimi, konumu nedeniyle geçiş iklimi özellikleri gösterir ve genel karakteriyle Akdeniz iklimi özelliklerini yansıtır (Anonim, 2018a). 2016 yılı verilerine göre ilde işgücüne katılma oranı \%48.6, istihdam oranı ise \%45.3 olarak gerçekleşmiştir (Anonim, 2017a).

2017 yılında Çanakkale ilinin ihracat değeri yaklaşık 124.7 milyon ABD\$ olup, ülke ihracat değerindeki payı \%0.08'dir. İlin ithalat değeri ise yaklaşık olarak 78.4 milyon ABD\$ olup, ülke ihracat değerindeki payı \%0.03 düzeyindedir. Çanakkale ili ülke genelinin aksine, 2017 yılında dış ticarette yaklaşık 46 milyon ABD\$ fazla vermiştir (Anonim, 2018e).

\section{Arazi Kullanım Durumu}

Çanakkale ilinin arazi varlığı (doğal göller ve baraj gölleri hariç tutulduğunda) 993 bin ha olup, ülke yüzölçümündeki (76.9 milyon ha) payı \%1.29'dur (Anonim, 2015). Türkiye'de 2017 yılı itibariyle Türkiye'de orman varlığı 22.3 milyon ha olup, Çanakkale ilinin (490 bin ha) payı \%2.19'dur. Ülke genelinde çayır ve mera alanı varlığı ise 14.6 milyon ha olup, Çanakkale ilinin (30 bin ha) aldığı pay sadece $\% 0.21$ düzeyindedir (Çizelge 1). miktarı (68.03 da) ülke geneline oranla (60.9 da) daha yüksektir. İlde 50 da'nın altındaki 32.5 bin adet küçük aile işletmesi için ortalama işletme büyüklüğü 34.2 da, 50 da199 da arasındaki 15.2 bin adet orta büyüklükteki aile işletmesi için ortalama arazi genişliği 118.5 da ve 200 da ve üzerindeki 976 adet büyük aile işletmesi için ortalama işletme genişliği 407.8 da'dır (Anonim, 2018a).

\section{Sulama Alt Yapısı}

Türkiye genelinde sulanabilir alanların $\% 65^{\prime}$ inde sulu tarım yapılırken, Çanakkale ilinde bu oran \%71 düzeyindedir. Ülke 
genelinde toplam tarım arazisinin \%19.5'lik kısmında sulu tarım yapılırken, ilde bu oran yaklaşık \%24'tür. Zira, Devlet Su İşleri (DSi) etüt sonuçlarına göre; Çanakkale ilinde 332 bin ha tarım arazisinin 113 bin ha'ı (\%34) sulamaya elverişlidir. Ancak ilde yaklaşık 80 bin ha alan sulanmaktadır (Anonim, 2018a). Tarla içi sulamada il genelinde damlama ve yağmurlama sulama yöntemi gibi basınçlı sulama sistemlerine geçmede önemli gelişmeler kaydedilmiştir. Bunun doğal bir sonucu olarak da özellikle sebze ve meyve alanlarında basınçlı sulama sistemleri ile sulama oranı \%92'ye ulaşmıştır. Bu seviyeye ulaşmada TOB tarafından basınçlı sulama sistemlerine uygulanan destek ve teşvikler ile bu sistemleri kuracak üreticilere sıfır faizli kredi uygulamasının önemli etkisi olmuştur.

\section{Çanakkale İlinde Tarımsal Üretim}

Türkiye'nin 2017 yılında tarımsal üretim değeri; 135.2 milyar Ł'si bitkisel üretim değeri ve 69.9 milyar Ł'si hayvansal ürünler üretim değeri (su ürünleri hariç) olmak üzere toplam 205.1 milyar Ł'dir (Anonim, 2018g,h). 2016 yılı verilerine göre Çanakkale ilinin su ürünleri üretim değeri (94.2 milyon Ł) ülke genelinden (4.6 milyar Ł) \%2.05 oranında pay almıştır (Anonim, 2017a,b). Su ürünlerine ait üretim değeri göz ardı edildiğinde, Çanakkale ilinin Türkiye tarımsal üretim değerindeki payı 2017 yılı verileriyle \%1.97 olup, bu pay hayvansal üretimde $\% 1.45$, bitkisel üretim de ise \%2.24 olarak gerçekleşmiştir. Çanakkale ilinde 2017 yılı birim fiyatlarıyla tarımsal üretim değeri yaklaşık 4.1 milyar $€$ düzeyinde gerçekleşmiştir (Çizelge 2).

Çizelge 2. Çanakkale ilinde tarımsal üretim değeri ve faaliyet kollarına dağılımı (2017)

\begin{tabular}{lllll}
\hline Üretim Dalları & Hayvansal Üretim & Bitkisel Üretim & Su Ürünleri & Toplam \\
\hline Üretim Değeri (Ł) & $1,013,958,418$ & $3,022,947,348$ & $87,803,934$ & $4,124,709,699$ \\
Payı (\%) & 24.58 & 73.29 & 2.13 & 100.00 \\
\hline
\end{tabular}

Kaynak: Anonim (2018a).

Tarımsal üretim değerinde bitkisel üretimin yapı $\% 73$, hayvansal üretiminin (su ürünleri dâhil) payı ise $\% 27^{\prime}$ dir. Çanakkale ilinin yaklaşık $670 \mathrm{~km}$ sahil şeridine sahip olmasına rağmen su ürünleri üretiminin il toplam tarımsal üretim değerindeki payı sadece \%2.13 düzeyinde kalmıştır (Çizelge 2).

\section{Bitkisel Üretim}

Illde ağırıklı olarak geleneksel yöntemle tarımsal üretim faaliyetleri sürdürülmektedir. Bununla birlikte alternatif tarımsal üretim yöntemlerinden Organik Tarım ve İyi Tarım Uygulamaları bakımından organik tarımda; Gökçeada, Ezine, Eceabat, Bozcaada, Ayvacık, ve Merkez İlçe, İyi Tarım Uygulamaları yönünden; Ezine, Merkez, Eceabat, Ayvacık, Bayramiç ve Lapseki ilçeleri ön plana çıkmaktadır. Çanakkale ilinde bitkisel üretimi oluşturan ana faaliyet dalları içinde tarla ürünleri yaklaşık \%38'lik oran ile ilk sırayı almaktadır. Sebze ve zeytin üretimi ise önemli görülen diğer tarımsal faaliyet kollarıdır (Çizelge 3).

Çizelge 3. Çanakkale ilinin bitkisel üretim değerleri (2017)

\begin{tabular}{lll}
\hline Üretim Dalları & Bitkisel Üretim Değeri (も) & Payı (\%) \\
\hline Tarla Ürünleri & $1,154,182,155$ & 38.18 \\
Sebze & $715,664,848$ & 23.67 \\
Zeytin & $411,268,200$ & 13.60 \\
Bağ & $69,006,600$ & 2.28 \\
Diğer Meyveler & $672,825,545$ & 22.27 \\
\hline Toplam & $3,022,947,348$ & 100.00 \\
\hline
\end{tabular}

Kaynak: Anonim (2018a).

Çanakkale ili tarımında önemli görülen ilk üç ürün; zeytin, buğday ve domatestir. İ ekonomisinde önemli görülen ürünler ve üretim değerleri Çizelge 4 'te verilmiştir. Illin bitkisel üretim değerinde ön planda yer alan 5 ürünün toplam bitkisel üretim değerindeki payı yaklaşık \%46'dır.

Çizelge 4. Çanakkale ilinde yetiştirilen önemli bitkisel ürünler (2017)

\begin{tabular}{llll}
\hline No & Ürün Adı & Üretim Değeri (Ł) & Payı (\%) \\
\hline 1 & Zeytin (Yağlık) & $354,901,800$ & 11.74 \\
2 & Buğday & $312,000,120$ & 10.32 \\
3 & Domates & $271,537,700$ & 8.98 \\
4 & Şeftali & $245,374,950$ & 8.12 \\
5 & Biber & $199,835,080$ & 6.61 \\
\hline Toplam & $1,383,649,650$ & 45.77 \\
\hline Genel Toplam & $3,022,947,348$ & 100.00 \\
\hline
\end{tabular}

Kaynak: Anonim (2018a).

Çanakkale ili şeftali üretiminde ülke genelinde yaklaşık \%16 oranında pay almaktadır. Bununla birlikte il; biber, zeytin ve domates üretiminde Türkiye genelinde ön sıralarda yer almaktadır (Çizelge 5).

Çizelge 5. İ Ekonomisinde Önemli Görülen Ürünlerin Ülke Genelindeki Payları (2017)

\begin{tabular}{lllll}
\hline No & Ürün Adı & $\begin{array}{l}\text { Çanakkale } \\
\text { (ton) }\end{array}$ & $\begin{array}{l}\text { Türkiye } \\
\text { (ton) }\end{array}$ & $\begin{array}{l}\text { İlin Payı } \\
\text { (\%) }\end{array}$ \\
\hline 1 & Zeytin & 173,062 & $2,100,000$ & 8.24 \\
2 & Buğday & 335,484 & $17,600,022$ & 1.91 \\
3 & Domates & 600,714 & $12,750,000$ & 4.71 \\
4 & Şeftali & 126,086 & 771,459 & 16.34 \\
5 & Biber & 235,712 & $2,473,978$ & 9.53 \\
\hline
\end{tabular}

Kaynak: Anonim (2018a,f).

İlin tarımsal üretim deseni ve üretim değerinde zeytin ve ürünlerinin ayrı bir yeri bulunmaktadır. Çanakkale ilinin sahip olduğu ekolojik özelliklerden dolayı kalite değerleri yüksek zeytinyağı üretiminin olması ve zeytinyağı 
üretiminde ilin tamamında modern ve yarı modern zeytin işleme tesislerinde üretim yapılması ürünün katma değerini daha da artırmaktadır (Anonim, 2018a). İlin ülke genelinde zeytin alanlarındaki payı \%4.93 iken üretim miktarındaki payı ise \%9.84 olmuştur. Buradaki temel faktör Çanakkale ilinde zeytin ağacı başına ortalama verim değeri $35 \mathrm{~kg}$ iken ülke genelinde bu değerin $16 \mathrm{~kg}$ düzeyinde kalmasıdır. İlde sofralık zeytin üretimi az olmasına rağmen, ağaç başına verim yine de ülke değerinin 3.3 katı daha yüksektir.

\section{Hayvansal Üretim}

Çanakkale ili tarımsal üretim değerinde hayvansal üretim $\% 24.58$ ve su ürünleri üretimi de $\% 2.13$ oranında pay almaktadır. İlin hayvansal üretim değerleri incelendiğinde en yüksek payı (\%72) süt üretimin, ikinci sırayı ise (\%19) et üretiminin aldığı anlaşılmaktadır (Çizelge 6).

Çizelge 6. Çanakkale ili hayvansal üretim değerleri (2017)

\begin{tabular}{lll}
\hline Ürünler & Üretim Değerleri (Ł) & Payı (\%) \\
\hline Süt & $733,713,702$ & 72.36 \\
Et & $192,527,560$ & 18.99 \\
Deri & $2,266,450$ & 0.22 \\
Yün & $1,394,481$ & 0.14 \\
Kıl & 141,059 & 0.01 \\
Yumurta & $17,222,373$ & 1.70 \\
Piliç Eti & $43,607,957$ & 4.30 \\
Bal & $23,084,835$ & 2.28 \\
\hline Hayvansal Üretim & $1,013,958,418$ & 100.00 \\
\hline
\end{tabular}

Kaynak: Anonim (2018a).

Çizelge 8. Çanakkale İlinde Büyükbaş Hayvan Varlığı (2017)

\begin{tabular}{llllll}
\hline Hayvanın Cinsi & Çanakkale (baş) & Genotipin Payı (\%) & Türkiye (baş) & Genotipin Payı (\%) & illin Payı (\%) \\
\hline Saf Kültür Irkı & 172,952 & 84.21 & $7,804,588$ & 48.97 & 2.22 \\
Kültür Melezi & 19,172 & 9.34 & $6,536,073$ & 41.02 & 0.29 \\
Yerli Sı̆̆ır & 13,236 & 6.45 & $1,602,925$ & 10.01 & 0.83 \\
\hline Toplam & 205,360 & 100.00 & $15,943,586$ & 100.00 & 1.29 \\
\hline
\end{tabular}

Kaynak: Anonim (2018a,1).

geneline oranla daha yüksek verim düzeyine sahip hayvan popülasyonundan oluştuğu anlaşılmaktadır. Ancak, ildeki hayvancılık işletmelerinin yaklaşık \%80'i 5-20 adet büyükbaş hayvan bulunan işletmelerden oluşmaktadır (Anonim, 2018a). İlin küçükbaş hayvan varlığı verileri ise Çizelge $9^{\prime}$ da verilmiştir.

Çanakkale ilinde küçükbaş hayvan varlığı yaklaşık 700 bin baş olup ülke genelinden aldığı pay yaklaşık \%1.60 düzeyindedir. İlin küçükbaş hayvan varlığında koyun

Çizelge 9. Çanakkale İlinde Küçükbaş Hayvan Varlığı (2017)

\begin{tabular}{llll}
\hline $\begin{array}{l}\text { Hayvanın } \\
\text { Cinsi }\end{array}$ & $\begin{array}{l}\text { Çanakkale } \\
\text { (baş) }\end{array}$ & $\begin{array}{l}\text { Türkiye } \\
\text { (baş) }\end{array}$ & $\begin{array}{l}\text { İlin Payı } \\
(\%)\end{array}$ \\
\hline Koyun & 458,250 & $33,677,636$ & 1.36 \\
Keçi & 238,500 & $10,634,672$ & 2.24 \\
\hline Toplam & 696,750 & $44,312,308$ & 1.57 \\
\hline
\end{tabular}

Kaynak: Anonim (2018a,1).
Çanakkale ilinin hayvansal ürünler üretim miktarı incelendiğinde ülke genelinde süt üretiminin \%2.63'lük pay aldığı, yapağı ve keçi kılında ise bu payın yaklaşık \%7 olduğu anlaşılmaktadır (Çizelge 7).

Çizelge 7. Çanakkale İlinde Hayvansal Üretim (2017)

\begin{tabular}{|c|c|c|c|}
\hline Ürünün Cinsi & Çanakkale & Türkiye & İlin Payı (\%) \\
\hline $\begin{array}{l}\text { Yumurta (milyon } \\
\text { adet) }\end{array}$ & 40 & 18,100 & 0.22 \\
\hline Kırmızı Et (ton) & 7,069 & $1,126,403$ & 0.63 \\
\hline Süt (ton) & 543,558 & $20,699,894$ & 2.63 \\
\hline Bal (ton) & 1,539 & 114,471 & 1.34 \\
\hline $\begin{array}{l}\text { Yapağı ve Kıl } \\
\text { (ton) }\end{array}$ & 743 & 11,241 & 6.61 \\
\hline
\end{tabular}

Kaynak: Anonim (2018a,1).

Çanakkale ilinin ülke genelinde bal üretimindeki payı \%1.5’e yaklaşırken, kırmızı et ve yumurta üretimindeki payı ise \%1'in de altında kalmıştır. İlin Türkiye süt üretimindeki payı sığır sütünde $\% 1.28$, koyun sütünde $\% 2.07$ iken bu pay keçi sütünde $\% 7.88$ düzeyine yükselmektedir. İlin büyükbaş hayvan varlığı Çizelge 8 'de verilmiştir.

Çizelge 8 incelendiğinde Çanakkale ilinde sığır varlığının yaklaşık \%84'ünün kültür ırkı sığırlardan oluştuğu görülürken, ülke genelinde bu oran yaklaşık \%49 düzeyinde kalmaktadır. Genel olarak bir değerlendirme yapıldığında ilin hayvan varlığının genotip özellikler açısından ülke varlığının payı \%65.77, keçi varlığının payı \%34.23'tür. Aynı oranlar Türkiye için sırasıyla \%76 ve \%24'tür. Bu paylar Çanakkale ilinde keçi yetiştiriciliğine ülke geneline oranla daha yüksek düzeyde önem verildiğini göstermektedir (Çizelge 9). Süt keçiciliğinde ildeki keçi varlığının yaklaşık \%65'i süt verimi yüksek Türk Saaneni (Saanen + Kıl Keçisi melezi) keçilerden oluşmaktadır. Bununla birlikte Çanakkale ili Türk Saaneni keçi varlığı ile Türkiye'nin en önemli damızlık merkezlerinden birisi konumundadır (Anonim, 2018a). Bu gelişmelerin doğal bir sonucu olarak da Çanakkale ili keçi sütü üretiminde yaklaşık 41 bin tonluk üretim ile Türkiye genelinden (523 bin ton) aldığı pay yaklaşık \%8 olmuş ve bu üretim faaliyetinde ülke genelinde ilk sıralarda yer almıştır.

\section{Su Ürünleri Üretimi ve Üretim Değerleri}

Çanakkale, Türkiye'de Muğla ilinden sonra en uzun kıyı uzunluğuna sahip bir il olması nedeniyle de önemli bir su 
ürünleri potansiyeline sahiptir. Mevcut balıkçı ve teknelerin (gerçek kişi su ürünleri ruhsatına sahip balıkçı sayısı yaklaşık 10 bin, ruhsatlı tekne sayısı 814 adet) yanı sıra zaman zaman diğer illerden avlanmak amacıyla gelen balıkçılar da dikkate alındığında, ilin birim av gücü potansiyelinin ülke genelindeki balıkçılık filosu içerisinde oldukça önemli bir Çizelge 10. Çanakkale ilinde su ürünleri üretimi ve üretim değerleri (2017)

\begin{tabular}{llll}
\hline Ürün Adı & Üretim Miktarı (ton) & Üretim Değeri (も) & Payı (\%) \\
\hline Deniz Avcılığı & 7,736 & $84,658,744$ & 96.41 \\
İç su Avcılığı & 4 & 14,120 & 0.16 \\
İç su Yetiştiriciliği & 308 & $2,703,000$ & 3.07 \\
Deniz Yetiştiriciliği & 50 & 428,070 & 0.36 \\
TOPLAM & 8,098 & $87,803,934$ & 100.00 \\
\hline
\end{tabular}

Kaynak: Anonim (2018a).

Çanakkale ilinde 2017 yılında toplam su ürünleri üretimi yaklaşık 8.1 bin ton olarak gerçekleşmiştir. Üretimde deniz avcılığının payı \%97 düzeyine yaklaşmıştır.

\section{Tarımsal Destekleme Uygulamaları}

Türkiye'de halen GTHB tarafından uygulanmakta olan tarımsal desteklemeler; bitkisel üretim, hayvansal üretim, yapısal iyileştirmeler, kırsal kalkınma ve çevre amaçlı desteklemeler olmak üzere 5 ana grupta değerlendirilebilir. yere sahip olduğu anlaşılmaktadır. Bununla birlikte Türkiye' de $A B$ üye ülkelere ihracat yapan su ürünleri işleme tesislerinin (96 adet) 8 adedi Çanakkale ilinde bulunmaktadır (Anonim, 2018a). Çanakkale ilinde su ürünleri üretimi ve üretim değerlerine ait bilgiler Çizelge 10 'da verilmiştir.
Çanakkale ilinde 2017 yılında GTHB tarafından üreticilere; 71.6 milyon Ł Hayvancılık, 55.6 milyon も Bitkisel Üretim ve 8.8 milyon Ł Kırsal Kalkınma desteklemeleri olmak üzere yaklaşık 136 milyon Ł destekleme ödemesi yapılmıştır. Üreticilere yapılan tarımsal desteklerde hayvancılık desteklerinin toplamdan aldığı payın \%50'nin üzerinde olduğu anlaşılmaktadır (Çizelge 11).

Çizelge 11. Çanakkale ilinde GTHB tarafından uygulanan tarımsal destekler (2017)

\begin{tabular}{llllllll}
\hline \multirow{2}{*}{ Yıllar } & $\begin{array}{l}\text { Hayvancılık } \\
\text { Destek (も) }\end{array}$ & $\begin{array}{l}\text { Bitkisel } \\
\text { Destekleri (も) }\end{array}$ & $\begin{array}{l}\text { Üretim } \\
\text { Yatırımlar (も) }\end{array}$ & $\begin{array}{l}\text { Ekonomik } \\
\text { Destek (も) }\end{array}$ & $\begin{array}{l}\text { Bireysel Sulama } \\
\text { Projeleri (も) }\end{array}$ & $\begin{array}{l}\text { Çiftçi Genel Toplam } \\
\text { (も) }\end{array}$ \\
\hline 2017 & $71,564,462$ & $55,618,553$ & 904,616 & 498,057 & $7,380,000$ & $135,965,688$ \\
\hline Payı (\%) & 52.63 & 40.91 & 0.67 & 0.37 & 5.43 & 100.00 \\
\hline
\end{tabular}

Kaynak: Anonim (2018a).

2017 yılında ülke genelinde uygulanan tarımsal destekler için yaklaşık 12.9 milyar Ł ödeme yapılmıştır. Destekleme

ödemelerinde ilk sırayı (\%30.45) arz açığı ürünlerin

desteklenmesine yönelik olarak verilen Fark Ödemesi Destekleri oluşturmuştur. Ikinci sırada ise \%29.83 ile hayvancılık destekleri, üçüncü sırayı ise alan bazlı destekler Çizelge 12. GTHB tarafından ülke genelinde uygulanan tarımsal destekler (2017)

\begin{tabular}{lll}
\hline Desteklemeler & Miktarı (Ł) & Payı (\%) \\
\hline Alan Bazlı Destekler & $2,696,883,000$ & 20.91 \\
Fark Ödemesi Destekleri & $3,927,947,000$ & 30.45 \\
Hayvancılık Destekleri & $3,848,326,000$ & 29.83 \\
Tarımsal Sigorta Destekleri & $853,518,000$ & 6.62 \\
Telafi Edici Ödemeler Kapsamındaki Destekler & $197,712,000$ & 1.53 \\
Diğer Tarımsal Destekler & $499,891,000$ & 3.88 \\
Kırsal Kalkınma Destekleri (Kırsal Kalkınma + Genç Çiftçi) & $793,894,000$ & 6.15 \\
Kırsal Kalkınma IPARD Destekleri & $81,000,000$ & 0.63 \\
\hline TOPLAM & $12,899,171,000$ & 100.00 \\
\hline
\end{tabular}

Kaynak: Anonim (2018i).

almıştır (Çizelge 12). Fark Ödemesi Destekleri, Hayvancılık

Destekleri ve Alan Bazlı Desteklerin toplam destekler içindeki payı \%81.19 olarak gerçekleşmiştir.

Çanakkale ilinde 2017 yılında ÇKS'ye kayıtlı çiftçi sayısı yaklaşık 22 bin, toplam destekleme tutarı 136 milyon $€$ ve

çiftçi başına düşen ortalama destek tutarı 6.2 bin Ł'dir. Türkiye genelinde aynı yıl ÇKS'ye kayıtlı çiftçi sayısı yaklaşık 2,1 milyon, toplam destekleme ödeme tutarı yaklaşık 12.9 milyar Ł ve çiftçi başına ortalama destek tutarı ise yaklaşık 6 bin Ł'dir (Çizelge 13). 
Çizelge 13. Çanakkale'de ve Türkiye'de Üretici Başına Tarımsal Destek Miktarı (2017)

\begin{tabular}{llll}
\hline Yerleşim Birimi & Tarımsal Destekler (も) & Çiftçi Sayısı (Adet) & Üretici Başına Tarımsal Destek Miktarı (も) \\
\hline Çanakkale & $135,965,688$ & 21,999 & $6,180.54$ \\
Türkiye & $12,899,171,000$ & $2,132,491$ & $6,048.87$ \\
illin Payı (\%) & 1.05 & 1.03 & - \\
\hline
\end{tabular}

Kaynak: Anonim (2018a,i).

Çanakkale ilinde 2017 yılında üretici başına ortalama tarımsal destekleme ödeme tutarı ülke genelinden \%2.17 daha fazla olmuştur. Konuyla ilgili olarak yapılan benzer bir çalışmada 2016 yılında Hatay ilinde çiftçi başına tarımsal destek ödeme tutarının Türkiye ortalamasının \%74.69 üzerinde olduğu tespit edilmiştir (Semerci, 2018).

\section{Alet-Makine Varlı̆̆ı}

2017 yılı itibariyle Çanakkale ilindeki tarım alet ve makinaları varlığı Çizelge 14 'te verilmiştir. Tüik verilerine Çizelge 14. Çanakkale ilinde Tarım Alet-Makinaları Varlığı (2017)

\begin{tabular}{llll}
\hline Alet-Makine Adı & Çanakkale & Türkiye & İlin Payı (\%) \\
\hline Mibzer $\left(^{*}\right)$ & 5,665 & 359,900 & 1.57 \\
Traktör & 26,177 & $1,306,736$ & 2.00 \\
Biçerdöver & 259 & 17,199 & 1.51 \\
Süt Sağım Tesisi & 151 & 12,226 & 1.24 \\
Süt Sağım Makinası (seyyar) & 11,085 & 319,885 & 3.47 \\
Pulverizatör $(* *)$ & 20,948 & $1,096,755$ & 1.91 \\
Silaj Makinası $(* * *)$ & 1,098 & 33,539 & 3.27 \\
\hline
\end{tabular}

Kaynak: TÜiK (2018j).

$\left({ }^{*}\right)$ :Traktörle Çek.Hub.Ekim Mak., Kombine Hububat Ekim Mak.

$\left({ }^{* *}\right)$ :Sırt Pülverizatörü, Sedyeli Mot.Pül.Toz., Kuy.Mil.Har.Pülverizatör, Motorlu Pülverizatör.

$(* * *)$ :Ot Silaj Makinası, Mısır Silaj Makinası

İlde hayvansal üretim ağırlıklı olarak süt sığırcılığına dayanmaktadır. Bu durum istatistiki verilerle de kendini göstermektedir. İldeki süt sağım makinası (seyyar) ve silaj makinası sayısı ülke değerinin $\% 3$ 'ten fazlasını oluşturmaktadır.

\section{Tarımsal Örgütlenme}

Çanakkale ilinde 2017 yılı itibariyle 1163 Sayılı Kooperatifler Kanununa göre faaliyet gösteren toplam tarımsal amaçlı kooperatif sayısı 372'tir. Bunun 309 tanesi Tarımsal Kalkınma Kooperatifi, 37 tanesi Sulama Kooperatifi ve 26 tanesi de Su Ürünleri Kooperatifidir. İldeki tarımsal amaçı toplam kooperatif sayısı ülke genelinin \%3.59'unu oluşturmaktadır. Bununla birlikte ilde 2017 yılı itibariyle 5,200 sayılı Üretici Birlikleri Kanununa göre kurulan 27 adet üretici birliği ve 5,996 Sayılı Veteriner Hizmetleri, Bitki Sağlı̆̆ı, Gıda ve Yem Kanunu'na göre kurulmuş 3 adet Yetiştirici Birliği mevcuttur (Anonim, 2018a).

\section{SONUÇ}

Çanakkale ili Türkiye'nin tarımsal üretim potansiyeli yüksek illeri arasında yer almaktadır. İ nüfusunun yaklaşık \%40'ı kırsal alanda yaşamakla birlikte, faal nüfusun yaklaşık $\% 35^{\prime} i$ tarım sektöründe istihdam edilmektedir. Bu nedenle ilde tarım sektörü il ekonomisinde önemli bir yere sahiptir. III, göre ildeki traktör varlığı ülke değerinin \%2'sini, biçerdöver ise $\% 1.51$ 'ini oluşturmaktadır. Toplam tarım alanı dikkate alındığında, Türkiye'de traktör başına 18.31 ha arazi düşerken bu değer Çanakkale ilinde 12.67 ha düzeyindedir. Aynı değerler biçerdöverde Türkiye için 1.2 bin ha, Çanakkale için yaklaşık 985 ha'dır. Hesaplanan değerler Çanakkale ilinde birim alan başına traktör ve biçerdöver sayısının ülke geneline oranla daha fazla olduğu ortaya koymaktadır (Çizelge 14). ) 
tarımsal örgütlenme anlamında ülke geneline oranla daha iyi durumda olunmasına rağmen, üretici örgütleri tarımsal ürünlerin pazarlanmasında ve fiyat oluşumunda istenilen düzeyde varlık gösterememektedir. Ancak kooperatifler ürünlerin depolanmasında sahip oldukları soğuk hava tesisleri ile ihtiyacın karşılanmasına önemli rol oynamaktadırlar. İlde üretilen sütün pazarlanmasında ve fiyat oluşumunda Tarımsal Kalkınma Kooperatifleri etkin konumdadırlar.

ilde tarım işletmelerinin sayısı yaklaşık 50 bin adet olup, ÇKS'ye kayıtlı işletme sayısı ise 22 bin civarındadır. Çanakkale ilindeki işletmeler genelde çok parçalı ve küçük ölçekli işletmelerdir. Bu işletmeler daha ziyade geçimlik tarım yapmaları nedeniyle gelirleri de düşük olmaktadır.

Çanakkale ilinde tarımsal üretimin daha verimli ve kârlı şartlarda yapılabilmesi için; nitelikli girdi kullanımının artırılması, sulama alt yapısına ağırlık verilmesi, tarımsal ürünlerin pazarlanmasında üretici örgütlerinin daha aktif rol almaları gerekmektedir. Küçük ölçekli işletmelerin de ÇKS sisteminde yer almalarının sağlanması halinde, üreticilerin gelir düzeylerinde artış sağlanabileceği gibi tarımsal ürün maliyetlerinde de kayda değer düşüşlerin görülmesi mümkündür.

\section{KAYNAKLAR}

Aktaş E, Tan S (2007) Tarım Politikasındaki Değişiklikler ve Bağcılık: Çanakkale ili Örneği. 2.Troas Bölgesi Değerleri Sempozyumu (17 Ağustos, 2007 Çanakkale). Bildiriler Kitabı s.199-211.

Aktürk D, Bayramoğlu Z, Savran F, Tatlıdil FF (2010) The Factors Affecting Milk Production and Milk Production Cost: Çanakkale Case - Biga. Kafkas Univ. Vet. Fak. Derg. 6 (2): 329-335.

Anonim (2005) Çanakkale İlinin Ekonomik Gelişmesi (Seminer). İktisadî Araştırmalar Vakfı. Yayın No: 2005180. İstanbul. $202 \quad$ s. (http://www.iav.org.tr/yonetim/dosya/seminer/cana kkkale.pdf, Erişim Tarihi: 16/07/2018)

Anonim (2011) Çanakkale Tarımı Sempozyumu (Dünü, Bugünü ve Geleceği).Bildiriler Kitabı. 746 s. ÇOMÜ Açık Erişim Sistemi.(http://acikerisim.lib.comu.edu.tr:8080/xmlui /handle/COMU/598, Erişim Tarihi: 16/07/2018)

Anonim (2014) Seçilmiş Göstergelerle Çanakkale-2013. Türkiye İstatistik Kurumu Matbaası, Ankara. Eylül 2014. Yayın No 4192. 179 s.

Anonim (2015) İstatistiklerle Türkiye-2014. Türkiye İstatistik Kurumu Yayın No:4380, s. 9. Ankara. Temmuz, 2015.

Anonim (2017a) Çanakkale Tarım ve Hayvancılık Yatırım Rehberi. Güney Marmara Kalkınma Ajansı. $25 \mathrm{~s}$. (https://www.gmka.gov.tr/dokumanlar/yayinlar/cana kkale_tarim_hayvancilik_rehberi.pdf, Erişim Tarihi: 16/07/2018).

Anonim (2017b) 22 Başlıkta İstatistiklerle TR22 Güney Marmara. Güney Marmara Kalkınma Ajansı. 124 s.
(https://www.gmka.gov.tr/dokumanlar/yayinlar/GMK A-22-Baslikta-Istatistiklerle-TR22-Guney-

Marmara.pdf, Erişim Tarihi: 16/07/2018).

Anonim (2018a) Tarım ve Orman Bakanlığı Çanakkale il Müd. $2017 \quad$ Yılı Brifing Dosyası. (https://canakkale.tarim.gov.tr/Menu/13/Brifingler, Erişim Tarihi: 12/07/2018),s.12

Anonim (2018b) Adrese Dayalı Nüfus Kayıt Sistemi Sonuçları-2016. Haber Bülteni. Sayı:27587,01.02.2018.

(http://www.tuik.gov.tr/HbGetirHTML.do?id=27587, Erişim Tarihi: 12/07/2018).

Anonim (2018c) Tarım ve Orman Bakanlığı. Makro Ekonomik Veriler. (https://www.tarim.gov.tr/Konular/Makro-EkonomikGostergeler, Erişim Tarihi: 21/06/2018).

Anonim (2018d) Fasıllara Göre ihracat ve Ithalat Değerleri.(http://www.tuik.gov.tr/PreTabloArama.do, Erişim Tarihi: 12/07/2018).

Anonim (2018e) illere Göre ihracat ve ithalat Değerleri.(http://www.tuik.gov.tr/PreTabloArama.do, Erişim Tarihi: 12/07/2018).

Anonim (2018f) Bitkisel Üretim Genel Müdürlüğü. Bitkisel Üretim Verileri. (http://www.tarim.gov.tr/sgb/Belgeler/SagMenuVeril er/BUGEM.pdf, Erişim Tarihi: 12/07/2018).

Anonim (2018g) Haber Bülteni, Sayı: 27842, 08 Mart 2018. (http://www.tuik.gov.tr/HbPrint.do?id=27842, Erişim Tarihi:13/07/2018)

Anonim (2018h) Haber Bülteni, Sayı: 27843, 28 Mart 2018. (http://www.tuik.gov.tr/PreHaberBultenleri.do?id=27 843, Erişim Tarihi: 13/07/2018)

Anonim (2018ı) Hayvancılık Genel Müdürlüğü. Hayvancılık Verileri.

(https://www.tarim.gov.tr/sgb/Belgeler/SagMenuVeri ler/HAYGEM.pdf, Erişim Tarihi:12/07/2018), s.2-4.

Anomim (2018i) Tarım ve Orman Bakanlığı. Faaliyet Raporu2017. (https://www.tarim.gov.tr/SGB/Belgeler/Bakanl \%C4\%B1k_Faaliyet_Raporlar\%C4\%B1/2017.pdf, Erişim Tarihi: 12/07/2018)

Anonim (2018j) Türkiye İstatistik Kurumu Veritabanı/Tarım/ Tarımsal Alet ve Makina İstatistikleri. (https://biruni.tuik.gov.tr/medas/?kn=134\&locale=tr, Erişim Tarihi: 17/07/2018)

Aydın B, Özkan E, Aktürk D, Kiracı MA, Hurma H (2015) Kırklareli, Edirne, Tekirdağ ve Çanakkale illerinde Üreticilerin İyi Tarım Uygulamalarına Yaklaşımı. Tarım Ekonomisi Araştırmaları Dergisi, 1 (2):28-41.

Aytüre S, Acar M (2016) Dünyada ve Türkiye'de Tarım ve Tarım Politikalarının Geleceği. Ekin Basım Yayın Dağıtım. Bursa. Türkiye. $415 \mathrm{~s}$.

Everest B, Tan S. ve Niyaz ÖC (2018) Tarım İşletmelerinin Örgütlenme Modelleri: Çanakkale İli Örneği. $7^{\text {th }}$ International Conference on Business Administration (ICBA), 3-5 Mayıs 2018, Canakkale, s.327-335. 
Ilgar R (2016) Çanakkale Iilinde Zeytin Yetiştiriciliği ve Yaşanan Sorunlar. İstanbul Üniversitesi Edebiyat Fakültesi Coğrafya Dergisi, 32:19-32.

Ilgar R (2017) Çanakkale Iilinde Tarımda Sürdürülebilirlik ve Organik Tarım. Doğu Coğrafya Dergisi, 22 (37): 159178.

Koyuncu E, Pala A, Savaş T, Konyalı A, Ataşoğlu C, Daş G, Ersoy iE, Uğur F, Yurtman iY, Yurt HH (2006) Çanakkale Koyun ve Keçi Yetiştiricileri Birliği Üyesi Keçicilik Iş̧letmelerinde Teknik Sorunların Belirlenmesi Üzerine bir Araştırma. Hayvansal Üretim, 47(1): 21-27.
Semerci A (2016) Effects of agricultural supports on farmer's revenue and product costs: The case of Turkey. Custos e @gronegócio on line, 12 (3): 71-96.

Semerci A (2018) Hatay illinde Tarım Sektörünün Yeri ve Önemi. Tarım Ekonomisi Araştırmaları Dergisi, 4(1): 36-47.

Tan S, Ortan Ü, Everest B (2014) Uygulamada Olan Tarım Politikaları Kapsamında Çanakkale'nin Mevcut Durumunun İncelenmesi Üzerine Bir Araştırma. ÇOMÜ Ziraat Fakültesi Dergisi, 2(1): 45-54. 
